\title{
The Hydra revisited: expectations and perceptions of the impact of the EU-Korea free trade agreement
}

\author{
Judith Cherry ${ }^{1}$
}

Received: 23 October 2016 / Revised: 29 April 2017 / Accepted: 30 April 2017 /

Published online: 25 May 2017

(C) The Author(s) 2017. This article is an open access publication

\begin{abstract}
On 1 July 2011, a free trade agreement was provisionally implemented between the EU and South Korea. At the time, there were clear expectations within the EU business community in Seoul about the likely impact of the deal, including an increase in EU exports, the dismantling of tariff and existing non-tariff barriers (NTBs), the possible emergence of new NTBs, the further development of mechanisms for discussion and problem-solving mechanisms, and a shift in Koreans' perceptions of all imported EU goods as luxury items. Interviews conducted with expatriate executives, diplomats and trade officials in Seoul in 2015 revealed the extent to which these expectations have been fulfilled and also highlighted the importance of broad economic and social trends in the strong performance of EU exports since 2011. These included the maturing of the Korean economy and the growing need for high-end industrial goods, and the Koreans' increasing purchasing power and the concomitant desire to engage in displays of wealth. In addition to contributing to the general academic debate on the impact of free trade agreements (FTAs) and adding specific colour to the case of the EUKorea FTA, this research will play an important role in shaping responses to the shifting economic, social and cultural trends that will impact the future outcomes of this key trade deal between the EU and Korea. It will also inform the EC's discussions with current and future free trade agreement partners and its analysis of the various factors influencing the actual and perceived success or failure of those deals.
\end{abstract}

This work was supported by the Academy of Korean Studies Grant AKS-2015-R05.

Judith Cherry

j.a.cherry@shef.ac.uk

1 School of East Asian Studies, University of Sheffield, 6-8 Shearwood Road, Sheffield, South Yorkshire S10 2TD, UK 


\section{Introduction}

Since the publication in 1950 of The Customs Union Issue, Jacob Viner's classic work on the trade creation effects of free trade agreements, much has been written in the academic literature about the benefits that member countries can expect to receive from negotiating and implementing these deals. The list of potential benefits for member country firms include enhanced terms of trade, higher trade volume, expanded market share, access to international supply chains and cheaper imported parts and components, economies of scale in production and a greater choice of manufacturing locations. In addition, the opening of the domestic market to foreign rivals and their products may serve as a catalyst for local firms to boost their competitiveness; consumers can expect to enjoy a wider range of competitively priced goods, and the creation of a more open, transparent and competitive business environment may play a key role in attracting trade and investment from both member and non-member countries (Krueger 1999, 20, 107; Urata 2002, 27-28; Dent 2006, 20; Goyal and Joshi 2006, 750).

On 6 October 2009, the European Union (EU) and the Republic of Korea ${ }^{1}$ initialled a free trade agreement (FTA), which provisionally went into effect on 1 July 2011. For the European Commission (EC), the FTA was the first such agreement negotiated under its 2006 'Global Europe' initiative and, for Korea, it formed part of an ambitious programme of bilateral and regional free trade negotiations that was launched in 1998. The FTA negotiations provided an opportunity for the Europeans to address barriers to trade and investment in an important market that offered good prospects for growth, but where EU firms faced the likelihood of being at a competitive disadvantage vis-à-vis competitors from countries who had already concluded, or were negotiating, free trade agreements with Korea. Another consideration for the EC was the market access issues that EU firms faced and that were raised with the Korean government on an annual basis.

Although much had been written in the academic literature about both the economic and political effects of free trade agreements and their anticipated impact on trade and investment, little had been published about the EU-Korea FTA in academic journals ahead of the implementation of the trade deal. ${ }^{2}$ In 2012, a project that considered the potential impact of the EU-Korea FTA from the perspective of the EU business community in Seoul made a fresh contribution to the existing academic literature on free trade agreements (Cherry 2012). Drawing on earlier research on barriers to trade and investment in post-crisis Korea (Cherry 2007) and based on a series of interviews carried out in September 2009 with European businessmen, diplomats and trade officials working in Seoul, the project sought to determine to what extent their expectations of the FTA's impact were aligned with the benefits and motivations highlighted in the academic literature of the time. The interviews revealed that European executives working in Seoul did not view the EU-Korea FTA as a panacea for the

\footnotetext{
${ }^{1}$ Hereafter 'Korea'.

${ }^{2}$ The exceptions included Andreosso-O'Callaghan's discussion of the viability of the agreement (AndreossoO'Callaghan 2009), Nicolas' exploration of the negotiating process (Nicolas 2009), and forecasts of the FTA's economic impact, most importantly the report published by Copenhagen Economics and François (2007).
} 
variety of challenges they faced in the market; rather they saw it as part of an ongoing process of seeking improvements in market access, signifying a change in and deepening of the relationship between Europe and Korea.

This article revisits the issue of the expectations that existed among the EU business community ahead of the implementation of the EU-Korea free trade agreement. In the autumn of 2015, a second series of interviews was conducted with expatriate executives working for EU businesses, and diplomats and officials assigned to EU embassies, diplomatic missions and trade organisations in Seoul. The two main areas of focus in the interviews were the developments in bilateral trade, and changes in the trade and business environment in Korea since the provisional implementation of the FTA in 2011. The insights provided by the interviewees enabled an analysis of the extent to which the earlier expectations among the EU business community in Korea had been met, 4 years after the deal went into effect, and also an assessment of whether the changes that had taken place were attributable to the trade deal or to other factors. Thus, this article provides fresh insights into the actual impact of free trade agreements that can inform the EC's strategy of pursuing FTAs, especially with newly - emerged economic powers.

\section{Preferential and free trade agreements ${ }^{3}$}

The term 'preferential trade agreement' (PTA) is widely used in the academic literature; using the typology developed by Balassa (1961), Krueger has identified several categories of PTA, namely free trade agreements (FTAs), under which tariffs are lowered relative to other members but are maintained against the outside world; customs unions, under which all tariffs among the members are eliminated while external tariffs are adjusted to a common level; common markets, which additionally allow for the free movement of factors of production, such as labour and capital, among the member countries; and economic unions, which also have common economic laws covering issues such as technical standards (1999, 111-112). The majority of trade agreements concluded in recent years have taken form of free trade agreements (Krueger 1999, 112), which Dent has defined as

A negotiated set of preferential market access concessions, trade-related rules and protected industry interests forged between signatory parties $(2007,458)$.

Although free trade agreements were originally restricted in scope to trade in manufactured goods, the nature of these deals has changed over time, with recent years witnessing a growing trend towards 'broad band', 'FTA-plus' or 'WTO-plus' agreements that also cover service sectors (including telecommunications, finance and law), foreign direct investment, government procurement, competition policy, intellectual property rights and the like, reflecting the shift from manufacturing to service sector trade and investment by developed countries (Dent 2010b, 20). Accordingly, there has been a change in focus from the dismantling of conventional trade barriers

\footnotetext{
${ }^{3}$ An earlier version of this theoretical framework appeared in Cherry 2012.
} 
to the area of business operations and 'commercial regulations', which Dent (2010a, 51) has defined as

The rules and standards that determine the regulatory framework in which the trade and investment related activities of firms take place.

The effects of free trade agreements can be divided into trade creation or diversion, and static or dynamic effects. Trade creation arising from an FTA derives from the dismantling of barriers to trade, which enables the more competitive producers within the signatory countries to increase their market share. In addition, member-country firms benefit from enhanced terms of trade and an increase in the volume of trade among them. The trade diversion effect occurs when goods manufactured by less efficient member-country firms replace those produced by more efficient non-member country firms, who continue to face the tariff barriers that have been removed for signatories to the deal (Krueger 1999, 107; Urata 2002, 27-28; Dent 2006, 20; Dai et al. 2014). In this context, Bhagwati emphasised the inherently discriminatory nature of free trade agreements, which derives from the fact that, by conferring benefits on signatories to the agreement, FTAs make trade 'freer for member countries than for non-member countries' (Bhagwati 2008, 1). In the short term, local firms gain from enhanced access to export markets and international supply chains and can source cheaper imported parts and components, while consumers enjoy a wider range of competitively-priced goods. The downside for the local manufacturers is the increase in competition in their home market; however, over time as more foreign firms enter the market, the negative effect of this increase in competition is 'more than offset' by the profits made in overseas markets (Goyal and Joshi 2006, 750). Dynamic effects of free trade agreements include market expansion effects as producers benefit from economies of scale and the opportunity to choose favourable production locations; competition enhancement effects as the market entry of foreign rivals prompts local firms to enhance their competitiveness; and collaboration effects, as member-country firms form strategic alliances to promote technology and skills development (Krueger 1999, 20; Urata 2002, 27-28). The opening of the market, the creation of a more open, transparent and competitive business environment, the attractions of the local consumer market and the desire to avoid tariff barriers can also be key factors in attracting inward foreign direct investment from member and non-member countries (Urata 2002, 27).

\section{The EU's free trade agreement with Korea-government expectations}

In 2006, the EC announced a new phase in its external trade policy with the publication of Global Europe: Competing in the World. A Contribution to the EU's Growth and Jobs Strategy. The rationale for the new strategy was the fostering of open markets through the pursuit of a new generation of bilateral and regional trade agreements that would boost trade and investment, and thus contribute to economic growth and job creation within the EU by acting as a powerful stimulus to competition, innovation and productivity growth (European Commission 2006). While offering assurances that it remained committed to the multilateral process led by the WTO and the successful 
conclusion of the Doha Round, the EC announced its intention to achieve the maximum benefits for the EU by negotiating 'deep' bilateral or regional agreements that went beyond the simple elimination of tariffs and included non-tariff barriers such as those relating to standards, certification and testing, intellectual property rights (IPR) and regulatory transparency (Guerin et al. 2007: ii-iv; European Commission 2006, 10-11).

There were three key commercial motivations for the Global Europe strategy: to minimise the negative impact of FTAs signed by trade partners and third countries (especially the potential trade diversion effects in favour of the USA), to forge strategic links with countries already experiencing high rates of growth or forecast to do so in the future, and to ensure the implementation of international commercial regulations such as those pertaining to the protection of IPR (Woolcock 2007, 4). The priority markets selected as potential FTA partners under the Global Europe strategy were ASEAN, South Korea and Mercosur (comprising Argentina, Brazil, Paraguay, Uruguay and Venezuela); in making its selection, the EC considered market potential (in terms of current and future market size and growth); the level of protection faced in the market by European exporters and investors; and the likelihood that European firms might be shut out or disadvantaged by bilateral agreements already being negotiated or considered with other trading partners. The focus on Asia reflected the growth in trade flows between Europe and Asia and the EC's desire to strengthen and enhance European links with the region (Gavin and Sindzingre 2009, 9; European Commission 2006, 11).

According to all the above-mentioned criteria, Korea was an obvious priority country for the new strategy. In terms of market size, a report published by the Centre for European Policy Studies and the Korea Institute for International and Economic Policy in 2007, the year in which FTA negotiations began, noted the importance of Korea to the EU in terms of trade, with Korea ranking as the EU's eighth most important trading partner and the EU ranking as Korea's fourth most important trading partner (Guerin et al. 2007, ii). A key motivation for the EC was the fact that Korea had already signed an FTA with the USA, a long-term political, diplomatic and commercial ally of the Koreans. The failure to ratify the Korea-US FTA gave the Europeans an opportunity to steal a march on their American competitors and raise the EU's profile in the region.

An important issue for the EC was the type of FTA to be signed with Korea; the key to achieving the maximum benefits for the EU was to conclude a 'deep' FTA that went beyond the simple elimination of tariffs and included areas such as non-tariff barriers, services, standards, IPR, and regulatory transparency (Guerin et al. 2007, ii-iv). This reflected concerns about the third criterion: non-tariff barriers to market access. Since the beginning of Korea's economic development in the early 1960s, successive governments have taken action to control and regulate foreign participation in the domestic economy. This action has ranged from the levying of punitive import duties and tariffs to the application of complex regulations and procedures, and the closure of selected sectors to foreign trade and investment. Although tariffs and duties have been lowered and the restrictions have been eased over the years (most notably following the implementation of liberalisation policies after the 1997 Asian Financial Crisis, in line with the conditions imposed by the International Monetary Fund for the rescue package offered to Korea), firms trading with and investing in Korea have continued to face problems in 'behind the border' market access and with regard to the commercial regulations that impact their day-to-day business activities. 


\section{The EU's free trade agreement with Korea-corporate expectations}

The European Commission's decision to pursue a free trade agreement with Korea under its 'Global Europe' strategy was based on a number of key motivations identified by scholars working in the field. An FTA with Korea would safeguard or improve access to the Korean market by eliminating existing barriers and monitoring the appearance of new ones, increase export opportunities for EU firms (bringing the benefits of increased trade and enhanced efficiency, productivity and economies of scale) and prevent the EU from being placed at a competitive disadvantage vis-à-vis competitor nations already active in the market and seeking to conclude similar deals with Korea. The FTA would also provide an opportunity for the EU to strengthen its international influence and enhance its position and profile in Korea and within the region.

Interviews conducted with the EU business community in September 2009 (Cherry 2012) supported the conclusions of scholars working in the field; with most tariffs at 'manageable levels', the real issues for the FTA to resolve were non-tariff barriers and issues relating to commercial regulations. In terms of the potential economic impact of the EU-Korea FTA, the interviewees anticipated an increase in trade but felt that, given the asymmetry of the deal in terms of the respective sizes of the EU and Korean markets, Korean firms were more likely to benefit in the short term. In terms of the elimination of conventional trade barriers, the key issue was the fact that, while lower tariffs would mean a visible boost to exports to Korea in some sectors in the short term, adverse exchange rate movements such as those experienced in the previous 2 years could quickly wipe out any gains from the gradual removal (over 3 to 5 years) of tariffs that averaged just $8 \%$. For some firms, lower tariffs would mean a chance to change the Koreans' perception that all imported goods were luxury goods, while others would seek to maintain that perception and re-invest their gains in promotional activities or introduce different products and models to the market.

The limited amount of research that was carried out into the potential impact of the EU-Korea FTA anticipated economic gains for both sides and highlighted specific industries that would benefit from the trade deal. The report by Copenhagen Economics and François predicted gains from liberalisation for both the EU and Korea, but forecast that two thirds of the total gains would go to Korea $(2007,4)$. In their assessment of the potential implications of the FTA, Guerin et al. picked the automobile industry as the biggest potential winner for Korea and identified the fine chemicals, food and beverages, and machinery industries as sectors with highly promising market prospects for the EU (2007, 98-102). The academic literature on the impact of free trade agreements and the interviews carried out ahead of the implementation of the EU-Korea FTA clearly showed that there were a number of ways, both objective and subjective, in which the impact of a free trade agreement could be measured. Relatively straightforward and objective assessments of the effect of an FTA included changes in the volume of trade and investment between the signatory parties and documented successes in removing non-tariff barriers. More subjective assessments could also be applied, largely derived from the perceptions of exporters and investors operating in a market, such as changes in the attitudes towards foreign capital, perceptions of foreign products in the local market, enhanced consistency, transparency and predictability in the regulatory environment, easier market access, and the creation of a more open, transparent and competitive business environment. 
However, as this research will demonstrate, even the relatively straightforward and objective measures of success can be influenced by factors beyond a pure 'FTA effect'.

\section{The EU-Korea FTA: 4 years on}

In order to determine the extent to which the expectations of the impact of the EUKorea FTA had been fulfilled or frustrated in the first 4 years of its implementation, and to judge the real impact of the FTA effect on EU exports to Korea, a second series of interviews were conducted in the autumn of 2015 with EU executives, diplomats and trade officials working in Seoul. In total, 39 expatriates took part in the interviews; these comprised existing contacts in the EU business community and the colleagues whom they had introduced as a pool of potential participants. Interviewees were then selected to take part, with a view to representing a range of nationalities, company sizes and industries across the manufacturing and financial sectors, that reflected, as far as possible, the EU's trading and investment interests in Korea The interviews, which were conducted in English by the author on an individual or small group basis, were semi-structured; this made it possible to combine a series of standardised questions with a more detailed discussion of interesting points that arose. All interviews were conducted on the condition of strict anonymity. The main issues discussed in the interviews were increased export opportunities for EU firms, perceptions of EU products, market access and non-tariff barriers, mechanisms for dialogue and problem-solving, the FTA effect and the importance of socio-economic change in Korea over the previous 4 years as a factor in the EU's success in Korea.

\section{Increased export opportunities}

Despite expectations that, in the short term at least, Korea was likely to be the bigger beneficiary of the bilateral trade deal, in the first 4 years ${ }^{4}$ of the implementation of the FTA EU exports to Korea, which had amounted to $€ 30.6$ billion in the 12 months preceding the implementation of the deal, had increased by $35 \%$ to $€ 47.3$ billion by the end of its fourth year in effect. The EU's share of Korea's imports increased from $9 \%$ in the year before implementation to $13 \%$ in the fourth year. ${ }^{5}$ Korean exports to the EU did not fare as well during the first 4 years of the FTA, edging up by just $5 \%$ to reach $€ 40$ billion by the end of June $2015 .^{6}$ Key reasons for South Korea's weak export performance and the increase in EU imports were the global financial crisis and resulting economic stagnation in Europe, the relocation of production bases to central

\footnotetext{
${ }^{4}$ The FTA was provisionally applied from 1 July 2011 and went into force formally on 13 December 2015, following ratification by all the EU member states.

${ }^{5}$ Korean official statistics for the period confirmed the general trends highlighted in the EC annual reports; see KOTRA 2014.

${ }^{6}$ Trade statistics published by Eurostat for the period January 2011 to December 2015 showed the impact of the EU-Korea FTA in the context of its trade with other countries. During this 4-year period, there was a $47.1 \%$ increase in EU exports to Korea; this compared with export growth rates of $40.5 \%$ for exports to the USA, $24.9 \%$ for China and $15.1 \%$ for Japan. The growth rate for EU imports from Korea stood at $16.8 \%$, compared to a $28.4 \%$ growth rate for imports from the USA, an $18.8 \%$ rise in imports from China, and a $15.2 \%$ fall in imports from Japan (Eurostat 2017).
} 
and eastern Europe by major Korean car and electronics firms seeking to gain access to lower production costs and local markets, and public procurement opportunities for EU firms created by a number of major government-driven initiatives in Korea (Cherry 2014). However, this small rise in imports from Korea compared favourably with the EU's global imports, which grew by just $2 \%$ in that period. Overall, the EU's trade deficit with Korea of $€ 7.6$ billion had been transformed into a surplus of $€ 7.3$ billion by June 2015 (European Commission 2016, 2-4).

Between 2010 and 2014, EU exports in services increased from $€ 7.4$ billion to $€ 11.9$ billion; Korean exports in services to the EU increased at a slightly slower rate, rising from $€ 4.7$ billion to $€ 6.0$ billion, giving the EU a trade balance in the services sector of $€ 5.9$ billion. Stocks of EU foreign direct investment in Korea had risen from $€ 37.5$ billion in 2010 to $€ 43.7$ billion in 2014 , while Korean stocks of FDI in the EU had increased from $€ 13.1$ billion to $€ 20.3$ billion in the same period (European Commission $2016,6)$. An EC report on the implementation of the FTA concluded that the agreement had 'worked very well' (European Commission 2016, 12) and the appraisal of the overall impact of the free trade agreement by the EC and by EU trade officials and diplomats working in Seoul in 2015 was equally positive. While it should be noted that, in the early years of the FTA, the impact of the agreement for EU member nations and companies varied according to the country and sector or industry (see Table 1), the overall trends in trade and investment suggested that the agreement had achieved the desired effect. As one EU trade official noted:

Looking at the big picture, it's very positive ... it is quite clear that the FTA did play a considerable role. There is a compelling case that the agreement is working well ... I cannot think of a sector that is really doing badly [FTA002].

\section{Perceptions of EU products}

In terms of the availability of EU consumer goods, there was a wider range of EU goods on sale in Korean retail outlets, and much higher visibility for EU luxury brands in sectors such as automobiles, fashion and alcoholic beverages than had been the case prior to the provisional implementation of the FTA in July 2011. Automobiles were the

Table 1 EU trade with Korea, by sector, 2012-2015 (in millions of Euros, percent)

\begin{tabular}{lllcllll}
\hline & 2012 & 2013 & Change & 2014 & Change & 2015 & Change \\
\hline Agricultural products & $€ 1180$ & $€ 1859$ & $57.5 \%$ & $€ 2197$ & $18.2 \%$ & $€ 2399$ & $9.2 \%$ \\
Food and raw materials & 2077 & 2143 & 3.2 & 2478 & 15.6 & 2710 & 9.4 \\
Fuels & 4643 & 4140 & -10.8 & 3966 & -3.5 & 3939 & -0.7 \\
Chemicals & 5780 & 5746 & -0.6 & 6148 & 7.0 & 6542 & 6.4 \\
Machinery & 17,483 & 19,557 & 11.8 & 21,557 & 10.2 & 24,293 & 12.7 \\
Textiles and clothing & 693 & 747 & 7.8 & 876 & 17.3 & 1051 & 20.0 \\
Total exports & 37.8 & 39.9 & 5.5 & 43.2 & 8.3 & 47.3 & 9.5 \\
\hline
\end{tabular}

Source: European Commission Directorate General for Trade (2017) 
most striking success, with sales of EU cars to Korea more than doubling; although the Koreans enjoyed an advantage in terms of the volume of automobile sales, EU manufacturers were clear winners in terms of the total value of cars exported, reflecting the number of high-priced luxury cars that were being shipped from the EU to Korea. Korea had become one of Jaguar-Landrover's fastest-growing markets (with plans to open 18 showrooms in Korea); Bentley sold more vehicles in Korea in 2014 than in any market in the world; and Mercedes Benz was experiencing strong year-on-year growth rates in sales [FTA003, FTA004, FTA005]. In the food and beverages sector, European wine and champagne were popular, sales of beer were strong and a good variety of European foods were entering Korea, including cheese which, once anathema to Koreans, was now regarded as sophisticated and was part of the new trend in fusion cuisine [FTA006, FTA010]. In the opinion of some interviewees, the implementation of the FTA had helped to overcome the negative feelings about people who had bought foreign luxury items such as expensive cars in the past. With the expectation that the FTA would lead to the expansion of Korean exports to the EU, it had become acceptable to buy luxury foreign goods, which were now viewed as desirable and prestigious items: as executives observed 'possessing and wearing foreign brands has changed hugely' [FTA005, FTA011]. There had also been a change in both the perception of what was considered to be a 'luxury' item (for a long time that had included most imported goods); lower- and middle-range European goods were now selling well and, as EU products became more affordable thanks to the reduction in or removal of tariffs, they were no longer regarded as luxury items.

\section{Market access and non-tariff barriers}

In 2009, expectations of the impact of the FTA had focused, to a great extent, on the non-tariff barriers (NTBs) that might remain even after tariffs were lowered or eliminated, and that the new generation of 'broadband' FTAs was aiming to resolve. In 2015, many of the interviewees confirmed that, 4 years in, most tariffs had been 'whittled away' and what remained were the non-tariff barriers. ${ }^{7}$ The 2009 interviews had highlighted a number of key issues relating to NTBs and commercial regulations, the most important of which were the use of non-EU standards and norms for products exported to Korea, the retesting and additional certification required for some EU imports, and the requirement that foreign financial services firms store and handle any data collected from Korean clients within Korea, rather than offshore. In addition, in the interviews carried out prior to the implementation of the FTA, one interviewee compared the process of dealing with NTBs in Korea to 'making friends with a Hydra', alluding to concerns among foreign executives and officials that, as soon as one NTB was eliminated, one or more new ones might appear in its place. The discussion of NTBs in 2015 began with an update on the key barriers identified in 2009, before moving on to persistent and newly-created barriers to trade.

With regard to standards and testing in general, one interviewee commented in 2015 on the positive impact of the FTA in terms of the harmonisation of standards and the

\footnotetext{
${ }^{7}$ Not all interviewees could provide examples of NTBs and some saw issues such as delays in customs clearance as frustrating 'from a timeline point of view' rather than as a barrier to their operations [FTA028].
} 
introduction of common testing criteria, which was creating 'more connectivity' than had existed a few years ago [FTA019]. In terms of standards, another interviewee noted that, in some cases, the FTA had indeed made things easier; a good example of this was the agreement to adopt EU standards for diesel cars in Korea, and American standards for petrol cars, rather than applying American standards across the industry (as had previously been the case) which created a potential barrier for EU manufacturers. A long-standing source of frustration and additional costs for EU firms selling certain products to Korea had been the requirement that they obtain prior certification in the form of a Korea Certification (KC) Standard Mark from authorised testing centres, regardless of any testing or certification that had been carried out in the country of production. The progress made in this area was, once again, evidenced most clearly by developments in the automobile industry; after negotiations over the certification of automobile parts, an agreement was reached under which the Koreans guaranteed that there would be no need to re-test the parts, and the EU accepted the requirement that parts sold in Korea should bear both safety marks. Thus, the NTB of incurring extra time and costs due to re-testing had been reduced to the much lower cost of physically adding the Korean mark to the product [FTA002]. In the case of other products, although it was now easier to get the $\mathrm{KC}$ mark than it had been in the past-EU firms could, for example, use testing centres in the EU rather than shipping their products to Korea for testing, as they had done in the past - the continuing requirement to comply with this standard created extra work and expense for EU firms. For one interviewee, this was a way of 'getting to the goal without really dissolving all the barriers' [FTA023]; while another agreed that 'It can be a barrier if you don't want to spend 5000 Euros to sort it out, to have it approved' [FTA031]. Another success related to the certification of organic food; although the Koreans had previously recognised EU certification with no need for re-testing, they had recently announced their intention to introduce a certification system based on their own testing processes. After EU protests on the basis that this was unthinkable, as Korea was a small market for EU producers of organic foods, the two sides successfully concluded a mutual recognition agreement [FTA002]. One interviewee suggested some possible motivations for the Korean authorities' continuing insistence on certification:

[The Koreans] think the world out there is dangerous and need to protect themselves from germs and diseases, faulty products and dangerous foods. Also ... protectionism (the most likely reason) and reciprocity - if a Korean product needs a US or EU certificate, the Koreans demand a KC certificate for US and EU goods [FTA008]

In 2009, a commonly cited example of a problematic NTB was the issue of allowing foreign firms in the financial sector to allow data outsourcing and the handling of data abroad. Although this issue was covered in one of the provisions of the FTA, its implementation was followed by a tough, 3-year battle as the necessary legislation was delayed, and appropriate regulations for the implementation of this important provision were not put in place. After three difficult years, there was a breakthrough, as one EU negotiator recalled: 
There was a moment where somebody in the (Korean) government said 'Why shouldn't we just do it and try to profit from it?' ...that is a change in mindset. They went beyond the commitments of the FTA, seeing ... the interests of their own country coinciding with the interests of foreign companies [FTA002]

Although there had been successes and cases where a negotiated settlement had been arrived at, some interviewees clearly felt that these were 'the exception more than the rule' [FTA002] and that those cases were 'easy wins', in as much as they were more cosmetic than effective, and allowed the Koreans to demonstrate a willingness to compromise, without making a structural changes to some of the big issues [FTA024]. A good example of this could be found in the pharmaceuticals sector, where foreign companies had long been frustrated by the Korean government's pricing policy. This set prices for pharma products at the lowest levels in the OECD and did not recognise or reward innovation and investment in research and development. As a result, the price reward for foreign products was so low that the headquarters of major EU pharma firms were reluctant to launch products in the Korean market. According to one industry source, the situation had actually deteriorated since the implementation of the FTA, as prices for foreign products were automatically reduced if their sales exceeded a set amount. The Korean authorities had announced that they would create a new mechanism to reward innovation but, as it would only apply to drugs that were developed in Korea by a foreign firm, or were developed overseas and had their global launch in Korea. This was seen as discriminatory by the EC and the change was dismissed by one interviewee as 'not realistic ... just cosmetic' [FTA030].

A significant difficulty in dealing with this new breed of NTBs was that they were often incident-specific, making it harder to deal with them. According to industry insiders, the increase in exports of EU automobiles to Korea in the years following the implementation of the FTA was followed by proposals in the National Assembly for the introduction of a number of regulations, which EU firms believed were aiming to limit their market share. These included the introduction of an upper price limit for company cars that qualified for tax deductions, and a proposal to change the basis for the annual vehicle tax from engine size to the value of the car. Both of these proposals would have negative implications for EU exports of high-priced automobiles to Korea [FTA008]. Also in the automobile sector, with a body width of $2.55 \mathrm{~m}$, EU buses (with the exception of double decker buses) were $55 \mathrm{~cm}$ too wide for Korean roads, which excluded EU manufacturers from the market.

In the area of agricultural products, EU farmers exporting meat to Korea still faced problems: while EU trade officials appreciated the Korean government's desire to apply strict health and hygiene standards, they felt that there was a lack of understanding of the EU system among their Korean counterparts and the safeguards it provided. In the case of an outbreak of, for example, avian flu, EU authorities would create a reasonable radius around the affected farm and, if there were no other cases, exports would continue. However, Korea had imposed a ban on all imports of Polish pork after an outbreak of African swine fever-a restriction that one EU official saw as a political move to protect Korean pork producers [FTA010] and poultry imports from the UK and Germany had been blocked because of one case of avian flu in each country. The approval process for importing fruit and vegetables was 'extremely painstaking' - approval for imports of kiwi fruit from Italy had taken 
7 years - and the requirement that all imported cheese must be pasteurised effectively banned imports of European cheeses made with raw milk, such as stilton and gorgonzola [FTA002].

Yet another market access issue came from the consumer electronics sector, where an EU company producing a part for a household product which could be imported tariff-free under the FTA, was informed that certification was needed for each of the product's 7 components. After modelling, checking and re-checking the testing and certification costs involved, the company realised that they could import their product to Korea but they could not sell it at a competitive price. None of the existing safety certifications for the product-awarded on a US, EU or global basis-was acceptable; Korean officials informed the company that, while having these certifications would speed up the process in Korea, they would still have to go through it [FTA011].

Two of the trade officials interviewed observed that, as Korea had signed more FTAs, so the number of NTBs had increased. However, they also noted that one impact of the FTA seemed to have been the need for a higher level of creativity when creating new hurdles to business, often in response to lobbying from Korean industries to come up with ways to make it more difficult for foreign firms to operate in the local market:

There is still a kind of protectionist spirit in Korea - where they can they will put up barriers. Where they can't, they will let it go. There is still a sense of looking to find barriers where they can [FTA011].

However, others argued that, in a large number of cases, the appearance of new NTBs was not happening 'because of a master plan to create obstacles'; rather it was a 'joined-up thinking issue', the result of changes being made to the regulatory framework without adequate consideration of the impact of those changes on foreign companies [FTA002].

\section{Mechanisms for dialogue and problem-solving}

The implementation of the EU-Korea FTA saw the creation of a consultation structure with 14 working groups for industrial sectors, which hold annual meetings at ministerial level, and a number of sub-groups that meet at different levels. This structure was assessed by one official as 'a good occasion once a year to talk about issues which we would not have otherwise' [FTA002] and there was regular dialogue between the EU and Korea through the FTA and 'associated conversations'. One executive whose business relied on close interaction with the government commented that the dialogue afforded him a privileged position in terms of access to Korean bureaucrats; reassuringly, he also reported that he and his colleagues had not needed to use that access to resolve any issues.

What has definitely been useful is using the EU representation as a channel to pass on information and messages ... not in a formal mediation or dispute 
situation but as a way to position ourselves or our offerings to the Korean government [FTA029].

An important negative aspect of the dialogue and complaint issue, which was highlighted by a number of interviewees, was that the EU's success during the first 4 years of the FTA had, in some respects, made it harder for EU officials to raise problems with their Korean counterparts. This was attributed to the 'win-lose' mentality observed by some interviewees among Korean bureaucrats; if the Koreans were not 'completely winning' in the post-FTA era, they were 'completely losing'. The Koreans were complaining that their expectations of the FTA had not been fulfilled [FTA012] and their disappointment made them reluctant to make more concessions. As one EU official observed:

The Koreans are not as happy as we are - for them, a trade deficit is a problem. Which means that, though we don't have too many implementation issues or market access issues ... they will be difficult to tackle, because the Koreans, every time there is a market access issue to be tackled, see it as a favour to someone who is already winning. It makes my job not very easy, because every time I call a ministry, the reply is "But why are you complaining when you are doing so well?" [FTA002]

This attitude was attributed to the pressure that the Korean government would likely be under from the National Assembly, media and general population, having promoted FTAs as a way to boost trade and develop the Korean economy [FTA020].

\section{The FTA effect and socio-economic change in Korea}

Interviewees concurred that, although the FTA had undoubtedly helped to boost EU exports to Korea, it was not the only factor in that success; in general terms, the increase in Korean imports from the EU reflected broader trends in the Korean economy and society, specifically shifts in perceptions of foreign luxury goods and changes in consumer behaviour. As one trade official observed:

Korea has been moving very quickly from a market of both consumer and industrial goods of average quality into a very strong demand for high-end products be it fashion, cars, or tools for industry. Korean industry became more mature and needed better tools and Europe is very good ... when it comes to high end sectors from fashion to electronics. That's what triggered - on top of the FTA - this change. Consumer tastes and the needs of the economy have changed, quite fast in fact and that has been a driver [FTA002]

Another interviewee highlighted the significant changes that have taken place in the Korean context in recent years: the rising standard of living, increasing purchasing power, greater levels of openness in Korean society, and higher numbers of Koreans (especially young people) travelling overseas, which had led to a greater awareness of, and desire for, foreign products. In short, they felt that it was difficult to assess 
accurately the impact of the FTA because Korea was so different, in many respects, from the country and market it had been 4 years ago [FTA021].

Focusing on a number of the EU's most successful export items, interviewees noted the impact of the change in consumer sentiment and behaviour, in particular the desire to spend money and possess high-end goods, both to impress others and to pamper themselves [FTA008]. The strong sales of certain European alcoholic beverages and foods reflected changes in the eating and drinking habits of Korean consumers, notably the popularity of organic foods, 'craft' beers and international and fusion cuisine. Interviewees noted that sales of European beers had been strong before the FTA went into force and remained strong after its implementation; while the FTA did not create growth in the sector, it encouraged the sustainability of growth that was boosted by a change from 'function to brand' among Korean beer drinkers, by reducing the tariffs on imported beers [FTA024]. Sales of wine and champagne had been boosted by the emergence of trendy clubs and bars targeting a young, internationalised, brand-conscious demographic, and a shift away from the focus on selling premium whisky to the older generation. Some interviewees concurred that the removal of tariffs was not the main reason for the rise in imports of European cars; while Korean cars had improved in terms of quality, prices had increased, narrowing the gap between domestic vehicles and imported luxury cars. Koreans were clearly willing and able to pay the higher prices for a premium car, but there were social changes at work too. Interviewees commented that many Koreans wanted to demonstrate their wealth and success, thus distinguishing themselves from their neighbours and co-workers. Given that, with the exception of the very wealthy, most Koreans lived in apartment blocks, they did not have the opportunity to demonstrate their wealth through the size or grandeur of their home. Thus, in Korea

It is hard to find a better way to distinguish yourself and to show your success to the outside world than in a luxury car. After all the hard work, they want to show the world ... "I made it!" [FTA025]

\section{Discussion and conclusions}

As the European Union and Korea moved towards the signing of a bilateral free trade agreement in 2009, there were clear expectations within the European Commission and the EU business community in Seoul about the likely impact of the deal. It was anticipated that there would be an increase in export opportunities for EU firms, but that Korean companies were likely to benefit more, at least in the short term. Although the 'broadband' FTA was designed to remove many of the key non-tariff barriers that were likely to serve as the main impediment to access to the Korean market once tariffs were lowered or eliminated, there were suspicions that, like the heads of the mythical Hydra, new NTBs would appear in their place. There was also an expectation that lower prices and the wider availability of EU goods would alter Koreans' perceptions that all imported goods were luxury items, and there was optimism that the FTA would assist with the further development of 
mechanisms for discussion and problem-solving between the EC and the Korean government.

In 2015, interviews were conducted with expatriate executives, diplomats and trade officials working in Seoul in order to assess the extent to which the original expectations of the trade deal have been fulfilled, and to analyse the various factors driving the increase in EU exports, above and beyond the FTA effect. Trade figures published by the European Commission clearly show that, during the first 4 years that the FTA has been in force, the EU has, contrary to expectations, seen more benefit from the deal than Korea and has experienced a significant increase in exports and a transformation of its chronic trade deficit into a trade surplus. ${ }^{8}$ As EU exports to Korea increased and the prices of many EU products fell (reflecting the lowering or elimination of tariffs), EU products have become more widely available and increasingly popular in Korea. Luxury goods from the EU are selling well, and perceptions of middle- to low-end products appear to be shifting from being 'luxury' to 'everyday' items. A number of key non-tariff barriers have been addressed (most notably within the automobile and the financial services sectors, and relating to standards, testing, certification and data management), mechanisms for discussion and problem-solving have been established and are working well, and there have been some signs of a shift in attitude among the Korean officials negotiating market access with their EU counterparts.

However, some of the negative expectations have also been fulfilled; there are examples of persistent and new barriers to market access (notably in the pharmaceuticals, automobiles and agricultural products sectors), suggesting that concerns over the ability of the Korean 'NTB Hydra' to keep growing new heads were well founded, and fuelling a degree of scepticism in some quarters about the Korean government's real commitment to free trade. Although mechanisms for discussion and problem solving are in place, the EU's success during the early years of the FTA appears to be acting as a constraint on the ability of EU diplomats and trade officials to raise new and existing market access issues with Korean officials, who seem to view their requests as unreasonable demands from the 'winning' side.

An important point that emerged from the interviews and discussions about the impact of the EU-Korea FTA and the factors in its success thus far, is the need to look beyond trade data and consider the various social, economic and cultural factors that have played a key role in fulfilling or frustrating the hopes and expectations on the European side. A number of the interviewees commented on the rapid speed at which Korea has changed in the years since the FTA was negotiated and highlighted the key role played by broad economic and social trends in the strong performance of EU exports. These included, inter alia: the maturing of the Korean economy and the growing need for the high-end industrial goods; the rising standard of living and the Koreans' increasing purchasing power, and the concomitant desire to engage in

\footnotetext{
${ }^{8}$ It should also be noted that, despite the rosy picture painted by trade officials and executives, the beneficial effects of the EU-Korea FTA have not been felt by all member states, or across all industries and sectors in the European Union. The asymmetric nature of the impact of, and gains from, the FTA has not been addressed in detail in this article and is clearly worthy of further investigation.
} 
displays of wealth; the shift in perceptions of imported luxury goods from unpatriotic purchases to objects of desire, and perceptions of imported middle- and low-end consumer goods from luxury goods to commonplace items; changes in consumer taste that have created new trends in dining and drinking and the impact of the boom in overseas travel which has exposed Koreans to foreign consumer goods, fashion, food and beverages.

In terms of the social and political factors that often work against the smooth implementation of the FTA, interviewees identified the frustration among the Korean bureaucrats who viewed the trade outcomes of the deal as a zero-sum game and had to face the lobbying of concerned local companies, and the politicians who needed to reassure the electorate about the benefits of signing FTAs and allowing increased levels of foreign goods and companies into the Korean market. Other factors were the lack of a holistic approach regarding Korean officials' response to requests from local business to bring in measures to help them maintain an advantage over foreign firms, and the nationalism and mercantilism that remain deeply embedded in some quarters of Korean business and political circles after decades of struggle to create and preserve a competitive advantage vis-à-vis foreign companies.

The EU's free trade agreement with Korea was the first in a new generation of trade deals under the 'Global Europe' initiative; drawing on the experiences and insights of the EU business community in Seoul, this research has provided critical and timely insights into the factors driving the success of this trade agreement. It has underlined the importance of looking beyond the FTA effect as measured by trends in trade and investment, and understanding the social, economic and political environment within which the FTA is being implemented. This includes shifts in consumer trends and behaviour and the perceptions and sensitivities of the bureaucracy, corporations and ordinary citizens of Korea. In addition to contributing to the general discussion about the impact of free trade agreements in the academic literature and adding specific colour to the case of the EU-Korea FTA, this understanding will play an important role in shaping responses to the shifting economic and social trends that will, inevitably, impact the future outcomes of this key trade deal between the European Union and the Republic of Korea. It will also inform the EC's discussions with current and future free trade agreement partners and its analysis of the factors influencing the actual and perceived success or failure of these deals.

Open Access This article is distributed under the terms of the Creative Commons Attribution 4.0 International License (http://creativecommons.org/licenses/by/4.0/), which permits unrestricted use, distribution, and reproduction in any medium, provided you give appropriate credit to the original author(s) and the source, provide a link to the Creative Commons license, and indicate if changes were made.

\section{References}

Andreosso-O’Callaghan B (2009) Economic structural complementarity: how viable is the Korea-EU FTA? J Econ Stud 36(2):147-167

Balassa B (1961) The theory of economic integration. Routledge Revivals, Abingdon

Bhagwati J (2008) Termites in the trading system: how preferential agreements undermine free trade. Oxford University Press, New York

Cherry, J (2007) Foreign direct investment in post-crisis Korea: European investors and 'mismatched globalization'. Routledge, Surrey 
Cherry, J (2012) Making friends with the Hydra: European expectations of the EU-Korea Free Trade Agreement. Eur J East Asian Stud 10(1):59-83

Cherry, J (2014) South Korea should keep calm and carry on through EU trade squall East Asia Forum, 2 August 2014

Copenhagen Economics, François J F (2007) Economic impact of a potential free trade agreement (FTA) between the European Union and South Korea. http://trade.ec.europa.eu/doclib/docs/2007 /march/tradoc_134017.pdf. Accessed 07 Apr 2017

Dai M, Yotov Yoto V, Zylkin T (2014) On the trade-diversion effects of free trade agreements. Econ Lett 122(2):321-325

Dent CM (2006) New free trade agreements in the Asia-pacific. Palgrave Macmillan, Basingstoke

Dent CM (2007) Full circle? Ideas and ordeals of creating a free trade area of the Asia-Pacific. Pacific Review 20(4):447-474

Dent CM (2010a) Freer trade, more regulation? Commercial regulatory provisions in Asia-Pacific free trade agreements. Compet Chang 14(1):48-79

Dent CM (2010b) Free trade agreements in the Asia-Pacific a decade on: evaluating the past, looking to the future. International Relations of the Asia-Pacific 10(2):201-245

European Commission (2006) Global Europe: competing in the world. Commission Staff Working Document, 16 October http://trade.ec.europa.eu/doclib/docs/2006/october/tradoc_130376.pdf. Accessed 07 Apr 2017

European Commission (2016) Report from the Commission to the European Parliament and the Council: Annual report on the implementation of the EU-Korea free trade agreement. http://trade.ec.europa. eu/doclib/docs/2016/june/tradoc_154699.pdf. Accessed 07 Apr 2017

European Commission Directorate General for Trade (2017) South Korea: Trade statistics. http://trade.ec. europa.eu/doclib/docs/2006/september/tradoc_111834.pdf. Accessed 07 Apr 2017

Eurostat (2017) Extra-EU28 trade, by main partners, total product. http://ec.europa.eu/eurostat/tgm/refreshTableAction. do?tab=table\&plugin $=1 \&$ pcode=tet00035\&language=en. Accessed 8 Apr 2017

Gavin B, Sindzingre A (2009) EU trade relations with emerging Asia: identifying the issues. Asia Europe Journal 7(1):9-22

Goyal S, Joshi S (2006) Bilateralism and free trade. Int Econ Rev 47(3):749-778

Guerin SS et al (2007) A qualitative analysis of a potential free trade agreement between the European Union and South Korea. Centre for European Policy Studies and Korea Institute for International and Economic Policy, Brussels

Korea Trade-Investment Promotion Agency (2014) Han-EU FTA 3 chunyŏn hyokkwa punsŏk mit sŏnggong sarye [the third anniversary of the Korea-EU FTA: analysis of its effect and success case studies] global market report 14-022. Korea Trade-Investment Promotion Agency, Seoul

Krueger AO (1999) Are preferential trading arrangements trade-liberalizing or protectionist? J Econ Perspect 13(4):105-124

Nicolas F (2009) Negotiating a Korea —EU free trade agreement: easier said than done. Asia Europe Journal $7(1): 23-42$

Urata S (2002) Globalization and the growth in free trade agreements. Asia-Pacific Review 9(1):20-32

Woolcock S (2007) European Union policy towards free trade agreements. ECIPE working paper 03/2000. European Centre for International Political Economy, Brussels 